\title{
PENINGKATAN VISIBILITAS BANGUNAN LAMA, STUDI KASUS JALAN KREMBANGAN BARAT SURABAYA
}

\author{
Setyo Nugroho \\ Program Studi Arsitektur, Sekolah Tinggi Teknik Stikma Internasional \\ Jl. Panji Suroso Blimbing, Malang \\ nuguroho@yahoo.com
}

\begin{abstract}
Abstrak
Makin derasnya pembangunan di pusat kota terkadang memaksa bangunan lama kehilangan eksistensinya. Penyebab hilangnya eksistensi bangunan adalah ketinggian bangunan baru yang menghalangi pandangan menuju bangunan lama, berubahnya sistem pergerakan arah lalu lintas kendaraan yang menyebabkan bangunan lama kehilangan wajah depannya, dan pemilihan jenis vegetasi yang kurang sesuai. Tulisan ini mengevaluasi tingkat visibilitas bangunan lama dan memberikan usulan rancangan skematik lingkungan di jalan Krembangan Barat Surabaya. Teknik analisis yang diterapkan adalah serial vision untuk mendapatkan pengalaman visual dan spasial terhadap sebuah lingkungan. Hasil menunjukkan terdapat tiga titik utama dalam koridor jalan yang dapat ditingkatkan visibilitas melalui: rehabilitasi dan adaptive re-use bangunan lama, serta penyediaan jalur pejalan kaki untuk menghubungkan titik-titik potensial yang ada di jalan Krembangan Barat.
\end{abstract}

Kata kunci: peningkatan visibilitas, bangunan lama, Krembangan Barat

\begin{abstract}
Title: The Improvement of Old Building Visibility, Krembangan Barat Street of Surabaya as of Case Study

High development in the City center forces old building losing its existence. The main factor old buildings losing its existences are the lack of skyline guideline (new buildings obstruct the view toward old buildings), the changes of traffic direction, and the selection of vegetation type. This paper discusses a brief evaluation of old building visibility through visual experiences, and gives a schematic design as proposal for jalan Krembangan Barat. Serial vision technique analysis is addressed in order to gain the visual and spatial experiences of the built environment. Result shows that three spots of place should be improved in order to perceive the visibility by rehabilitating, adaptive re-using, and providing pedestrian ways to connect one potential spot to others in the corridor of Krembangan Barat.
\end{abstract}

Keywords: visibility improvement, old buildings, Krembangan Barat

\section{Pendahuluan}

Dalam konteks skala kota, bangunan dilihat secara mengelompok dan perspektif (cenderung menghilang pada satu titik hilang). Sehingga pengamat tidak akan fokus pada satu bangunan dan detailnya, melainkan pada deretan dan bangunan sekitarnya Jika diamati secara mengelompok, keberadaan bangunan lama di jalan Krembangan Barat tidak menonjol. Tingkat visibilitas urban landmark dapat menonjol jika pemilihan vegetasi tepat, dan ketinggian bangunan sekitar yang teratur. Maju mundurnya bangunan baru juga dapat menyebabkan makin 
mudah atau sulitnya pengamat di tahun 1990an hingga 2000an. menangkap visibilitas bangunan. Namun penggunaan metode segmentasi Permasalahan hilangnya bangunan data tiap sikuen belum pernah lama sebagai elemen focal point dilakukan sebelumnya. Metode menjadi salah satu faktor penyebab segmentasi data yang diuraikan oleh sebuah kawasan kehilangan makna Kalin dan Yilmaz (2012) awalnya ruangnya (Trancik, 1986). Menurut digunakan untuk melihat visibilitas penelitian yang telah dilakukan Hagia Sophia (hanya satu obyek) di sebelumnya berkaitan dengan focal point di jalan Krembangan Barat, terdapat enam bangunan lama yang menjadi focal point (Nugroho et al, 2014). Titik focal point bangunan dapat dilihat pada Gambar 1. Bangunanbangunan ini memiliki ketinggian yang dominan dalam lingkungan sekitar, posisi yang baik pada persimpangan maupun sudut jalan sehingga pengamat mudah melihat dan diarahkan.

Penelitian yang pernah dilakukan adalah mengkaji tingkat visibilitas jalan Krembangan Barat dari arah selatan ke utara. Hasil penelitian sebelumnya (Nugroho et al, 2013) menjelaskan bahwa pada pandangan dari arah selatan ke utara, bangunan lama sebagai focal point terhalang oleh vegetasi pohon dengan karakter bulat dan tidak didukung oleh penataan infrastruktur yang baik. Walaupun bentuk jalan mendukung dalam menangkap visibilitas bangunan, namun pemilihan jenis vegetasi juga menjadi pertimbangan yang penting. Berangkat dari hasil penelitian sebelumnya, maka artikel ini mencoba untuk mengkaji seberapa besar tingkat visibilitas bangunan lama dari arah utara ke selatan (arah sebaliknya) sehingga mendapatkan hasil yang komprehensif, dan bagaimana usulan rancangan agar visibilitas bangunan dapat tertangkap dengan baik.

Studi mengenai kajian sikuensial dan visibilitas telah dilakukan sejak awal periode modern. Berangkat dari Cullen (1961), kajian sikuensial berkembang dalam lansekap perkotaan. Di dalam paper ini, metode yang sama diterapkan dalam melihat beberapa obyek bangunan yang disebut dengan focal point di dalam lingkungan yang padat.

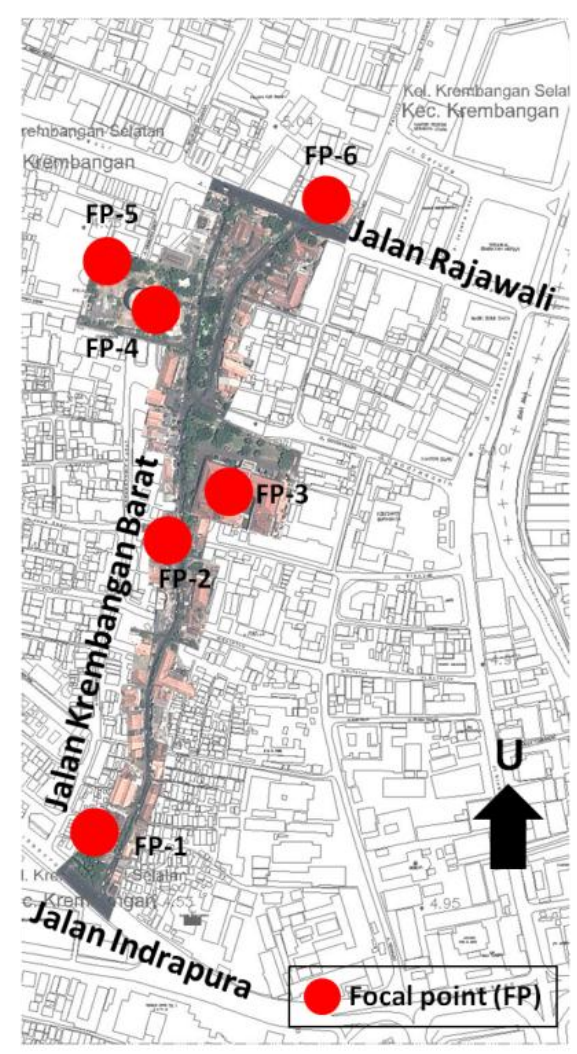

Gambar 1. Koridor jalan Krembangan

Barat.

Sumber: Dokumentasi Nugroho, 2015

Di dalam catatan sejarah, koridor ini merupakan bagian paling barat dari sebuah tembok kota (Kwanda, 2011). Sebuah benteng dan konstruksi tembok kota pernah berdiri di dalam area ini. Namun pada tahun 1870 dirobohkan untuk kepentingan pengembangan dan pembangunan infrastruktur kota Surabaya. Kini, jalan Krembangan 
Barat lebih berperan menjadi jalur alternatif penghubung dari jalan Indrapura menuju jalan Rajawali.

Secara administratif, lokasi ini masuk dalam Kelurahan Krembangan Selatan, Kecamatan Krembangan, kota Surabaya dengan pola penggunaan lahan adalah campuran antara jasa, perdagangan, dan permukiman. Batas fisik penelitian berupa jalan dengan satu unit bangunan terluarnya sehingga membentuk ruang koridor.

\section{Kajian Sikuensial}

Menurut Cullen (1961), bangunan tunggal yang berdiri di sebuah tanah lapang dapat disebut dengan karya arsitektur, tetapi selusin bangunan yang membentuk rangkaian tersendiri akan membentuk sebuah seni yang lebih dari arsitektur. Cullen (1961) menjelaskan konsep townscape dalam bentuk serial vision yakni susunan sikuen yang dibentuk secara serial, urut, bersinambung, dan menerus yang di dalamnya terkandung existing view dan emerging view. Sikuen adalah penggal jalur atau lorong lintasan gerakan manusia dari titik awal (origin) ke titik akhir (destination) dan masing-masing menyajikan tampilan dan makna. Cullen (1961) menambahkan bahwa pada setiap sikuen dari serial vision terdapat sebuah cerita. Susunan cerita ini merupakan upaya manusia dalam memanipulasi situasi ruang dalam menimbulkan rangsangan emosi dan kesan. Pada nantinya di setiap cerita pengamat akan mengalami perasaan terkejut, gembira, tertekan, penasaran, dan lainnya. Cerita ini dibagi menjadi dua yakni: place (posisi) dan content (isi) (Cullen, 1961:11).

Place (sense of position) berkaitan dengan reaksi posisi pada setiap orang terhadap lingkungan melalui pengalaman ruang. Salah satu penerapan reaksi tubuh kita terhadap lingkungan adalah here and there, pengamat berada di sini dan obyek yang diamati berada di sana (Cullen, 1961). Konsep ini merupakan kondisi yang umum dari sebuah setting lingkungan tergantung pada penekanan yang lebih spesifik terhadap obyek. Sedangkan content merupakan isi dari konsep place yang berkaitan dengan urban fabric (bentuk fisik dari sebuah kota). Bentuk fisik ini dapat kita ketahui melalui warna, tekstur, skala, gaya, karakter, sifat atau kepribadian, dan keunikan (Cullen, 1961). Namun bukan hanya sekedar yang dibatasi oleh bidang-bidang fisik, dalam content banyak makna dan kegiatan masyarakat setempat yang terkandung. Cullen (1961) menambahkan, place merupakan perpaduan dari space (ruang) dan content (makna dan kegiatan). Dengan kata lain keberadaan place tidak dapat dipisahkan dari content.

Sepaham dengan konsep serial vision dari Cullen (1961), McCluskey (1992) memaparkan bahwa bangunan, jalan, vegetasi, dan elemen lansekap lainnya secara bersamaan ada di persepsi setiap orang, dan jalan dilihat sebagai keseluruhan komposisi. Jalan dapat dianalogikan sebagai sebuah ruang atau serial ruang. Permukaan jalan adalah lantai, bangunan dan atau vegetasi sebagai dinding, dan ranting pohon atau kanopi bangunan atau langit sebagai plafond (McCluskey, 1992). Dia menambahkan bahwa sebuah jalan akan memiliki nilai ketertarikan jika sebuah jalan itu memiliki focal point (struktur, bangunan, atau elemen yang ditonjolkan) pada saat pengamat, baik berjalan kaki maupun mengendarai kendaraan, mendekati bagian akhir penggal jalan (McCluskey, 1992). 
Serial vision berarti terdapat perubahan obyek yang diamati sesuai dengan posisi pengamat. Dengan kata lain saat pengamat berjalan maju maupun mundur, kesan ruang yang dihasilkan atau yang ditangkap akan selalu berubah. Perubahan pada lingkungan perkotaan ini disusun oleh jalur dan tempat. Jalur dikaitkan dengan pergerakan dari tempat satu menuju tempat lain yang menghasilkan perubahan pandangan. Sedangkan tempat dikaitkan dengan ruang yang diam, mendapatkan enclosure ruang, dan sense of place. Lingkungan ini disebut sebagai 'system of place' dengan jalur yang merupakan 'dynamic space' dan tempat adalah 'static space' (McCluskey,1992: 92). Skematik konsep system of place menjelaskan secara umum bentuk lingkungan perkotaan yang terbagi menjadi dua jenis: static space, dan dynamic space (Gambar 2).

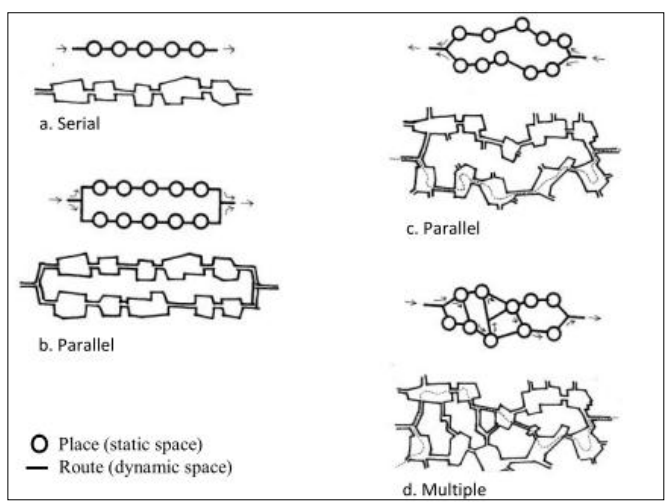

Gambar 2. Skematik dari konsep 'system of place'.

Sumber: McCluskey (1992)

Pada tipe (a), ruang-ruang statik dihubungkan dengan satu ruang dinamik yang dapat berbentuk formal maupun informal. Tipe (b) dan tipe (c) serupa dengan model paralel. Namun pada tipe (c) kesan sense of place akan lebih terasa dari pada tipe (b), karena ruang-ruang statik dihubungkan dengan garis yang tidak lurus melainkan lebih organik. Tipe (d) adalah tipe yang dikembangkan dari tipe-tipe sebelumnya. Pada tipe ini kekompleksan ruang tercapai dengan saling berpotongannya ruang statik satu dengan ruang dinamik yang lain, sehingga pilihan dan kemungkinan untuk menikmati lingkungan perkotaan lebih banyak.

Beberapa penelitian terbaru mengenai kajian sikuensial dalam lima tahun terakhir dilakukan oleh Kalin dan Yilmaz (2012), Almazan et al (2012), serta Rollo dan Barker (2013). Seperti yang dijelaskan sebelumnya, Kalin dan Yilmaz (2012) menggunakan metode segmentasi data dengan cara menyederhanakan gambar melalui teknik arsir. Arsir gelap menandakan bangunan yang menjadi target obyek pengamatan. Teknik ini berguna untuk mengetahui di titik sikuen mana obyek memiliki pandangan terbaik dan yang kurang baik. Almazan et al (2012) menerapkan kajian serial vision untuk mengamati seberapa besar proporsi elemen vegetasi pada suatu lingkungan permukiman. Teknik yang digunakan adalah mengekstrak foto vegetasi dengan software Adobe Photoshop kemudian dikuantifikasi melalui jumlah pixel pada tiap foto. Tujuan dari teknik ini adalah mengetahui potensi penghijauan dalam meningkatkan urban scenery.

Sedangkan Rollo dan Barker (2013) melakukan eksperimen dengan cara melibatkan responden untuk menilai dan mengevaluasi pengalaman dalam menyusuri ruang berdasarkan persepsi yang menyenangkan dan yang tidak. Persepsi yang ditangkap oleh responden lalu difoto menggunakan kamera digital. Setelah mengetahui pemetaan persepsi responden, maka diperoleh apa yang sebaiknya ditambahkan atau diperbaiki untuk meningkatkan kualitas ruang atau jalan. 
Dari beberapa penelitian terdahulu, teknik yang diterapkan oleh Kalin dan Yilmaz (2012) yang paling mendekati dengan tujuan penulisan artikel ini. Dipadukan dengan hasil penelitian sebelumnya (Nugroho et al, 2013), sehingga diperoleh hasil yang lebih komprehensif.

\section{Metodologi}

Jenis penelitian yang digunakan adalah penelitian deskriptif dengan menggunakan metode kualitatif. Strategi pengumpulan data sesuai yang diutarakan Cullen (1961) yaitu pengamatan dengan cara fokus pandangan serial (serial vision) pada sebuah penggal jalan yang alurnya telah ditentukan. Teknik analisis yang diterapkan adalah serial vision. Teknik analisis serial vision mencoba memberikan sebuah penilaian pada lingkungan fisik kota. Teknik ini merupakan alat visualisasi langkah pada sebuah alur (sepanjang) jalan tertentu untuk memberikan informasi dan kejelasan dari komponen fisik yang ditangkap. Di sepanjang alur yang ditentukan kemudian dijelaskan informasi apa yang ditangkap (fakta kota, potensi kawasan, kesan ruang pada sebuah sikuen) (Al-Kodmany, 2001).

Pada pandangan sikuensial, foto diambil dalam jarak kurang lebih setiap 10 meter dengan ketinggian kurang lebih 1,5 meter. Foto diambil dari sudut pandang pejalan kaki, dimana pengalaman ruang lebih banyak dirasakan. Sehingga pandangan hasil foto yang direkam tidak persis lurus ke depan.

Karena jarak demikian relatif dekat maka kemungkinan akan ada foto yang identik. Untuk mendapatkan foto dengan sikuensial yang baik, beberapa foto yang identik sebaiknya dihapus (Kalin dan Yilmaz, 2012). Foto yang ditangkap kemudian disusun dan disederhanakan menggunakan teknik penyajian segmentasi data (Gambar 3).

Teknik ini bermanfaat untuk mengevaluasi tingginya dominasi bangunan lama sebagai bangunan penting dalam satu penggal jalan maupun kawasan (Kalin dan Yilmaz, 2012). Tahapannya antara lain: foto berwarna diubah ke dalam foto hitam putih, kemudian tiap properti (pohon, jalan, dan bangunan penting) dibedakan arsirannya. Pengolahan data ini menggunakan perangkat lunak AutoCAD.

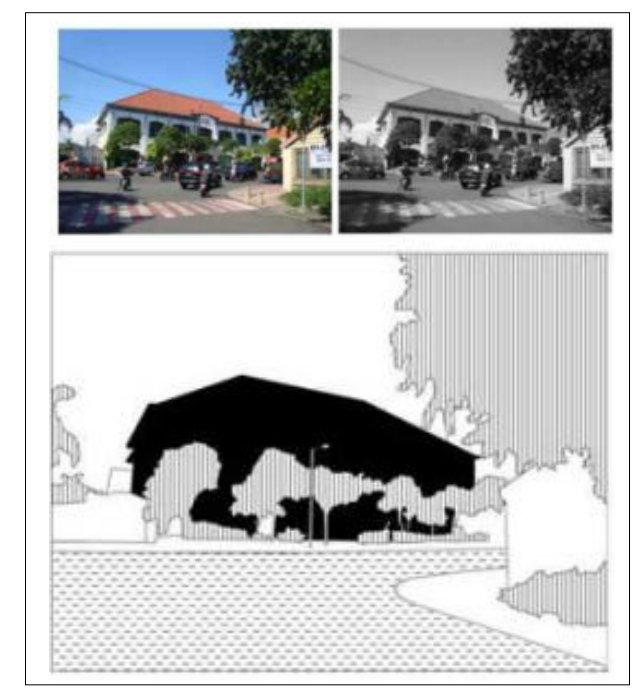

Gambar 3. Teknik segmentasi pada penyajian data.

Sumber: Nugroho, 2013; berdasarkan pemahaman Kalin dan Yilmaz (2012) 


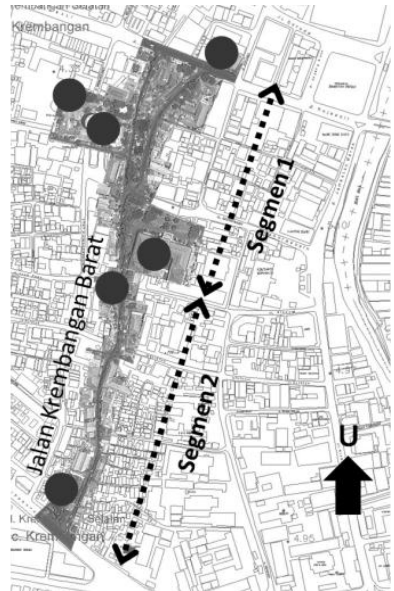

Gambar 4. Pembagian segmen pada lingkup penelitian.

Sumber: Dokumentasi Nugroho, 2015.
Penyajian data analisis serial vision dibagi menjadi dua bagian: segmen 1 dan 2. Pada tiap segmen dijelaskan tingkat visibilitas dan pengalaman ruang yang ditangkap berdasarkan kajian sikuensial. Pembagian segmen dapat dilihat pada Gambar 4.

Tabel 1. Segmen 1 (Arah Utara ke Selatan)

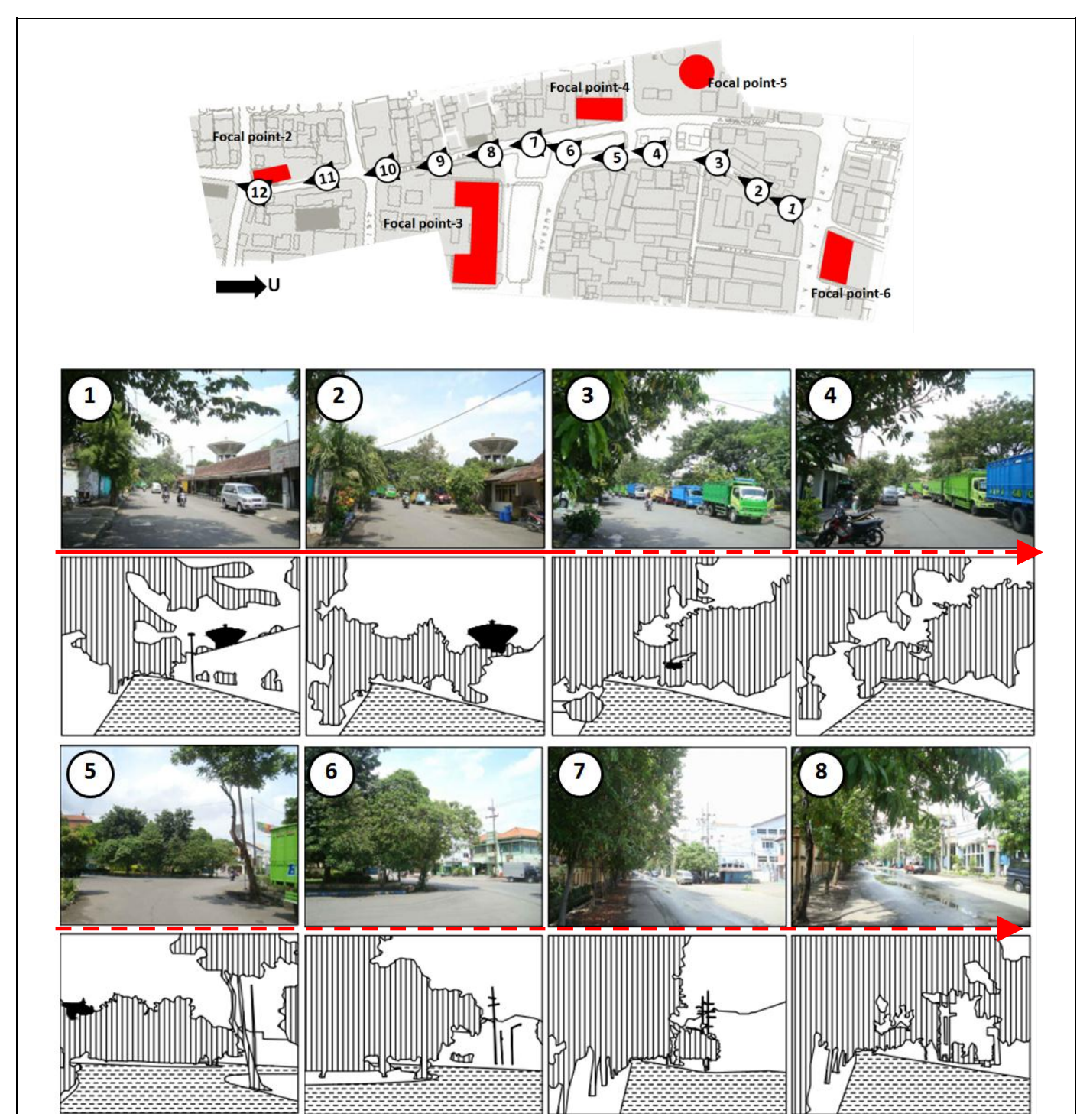




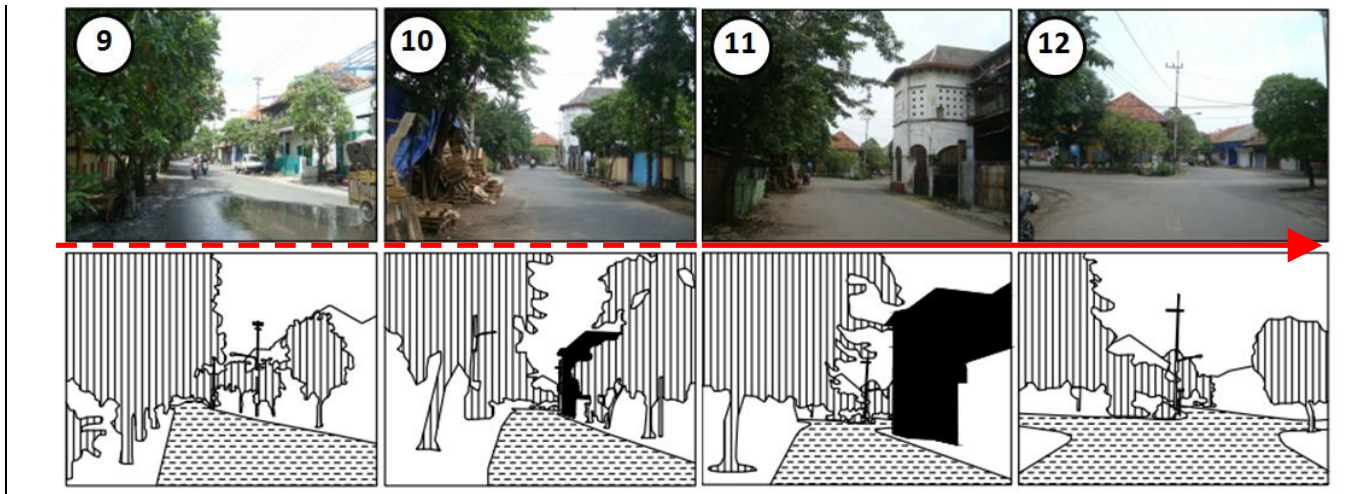

Sumber: Hasil Analisis, 2014

\section{Hasil dan Pembahasan}

\section{Analisis Serial Vision Segmen 1}

Tabel 1 menunjukkan segmen 1 yang terdiri dari 12 frames dengan jumlah lima focal points. Pada frame 1 hingga 5 tertangkap visibilitas dari menara air (focal point-5) dengan jelas, khususnya pada frame 2. Hal ini disebabkan oleh ketinggian bangunan menara yang dominan jika dibandingkan dengan bangunan sekitar. Sehingga walaupun tampak jauh dan terhalang oleh bangunan di latar depan, menara dapat mudah tertangkap dalam beberapa sikuen.

Saat pengamat maju terus ke arah selatan, maka mereka akan disambut oleh focal point-3. Kualitas transparansi ruang diciptakan melalui elemen vegetasi pohon yang dominan dalam koridor jalan. Namun lingkungan yang teduh tidak dilengkapi dengan jalur pejalan kaki yang layak. Pada penyajian data dengan cara segmentasi, bagian atap dan kemuncak focal point-3 terlihat pada frame 5 . Walaupun terlihat bagian atas atap dan kemuncaknya, namun pada foto berwarna tidak tampak jelas visibilitasnya. Ini disebabkan oleh jenis vegetasi pohon peneduh yang gemuk dan bulat menutup bagian badan bangunan. Dengan kata lain, segmentasi data membuktikan lebih mudahnya menangkap bagian bangunan yang menjadi focal point.

Dari frame 5, pengamat dibelokkan menuju jalan baru di frame 6. Intensitas vegetasi pohon sangat tinggi dari frame 6 sampai frame 9, hingga akhirnya pengamat menemukan bagian dari focal point- 2 di frame 10 dan semakin jelas pada frame 11. Pandangan pada segmen ini hanya dapat diamati oleh pejalan kaki di mana pejalan kaki melihat jelas bagian bangunan dari focal point-2 yang menjorok ke bahu jalan. Pejalan kaki yang berjalan di tepi tampak akan menembus colonnade pada focal point-2. Bentuk bangunan dengan colonnade seperti ini tidak dijumpai di bangunan lain. Setelah visual tertangkap pada frame 11 pengamat akan menemukan sebuah persimpangan yang baru saat mendekat.

Jika diamati kembali dari sisi spasial, setelah titik origin deretan bangunan yang padat (dari frame 1 hingga 4) kemudian menciptakan ruang yang lapang, vistas. Vistas seharusnya mampu menciptakan tampilan yang menyenangkan pada focal point-3. Visibilitasnya dapat tercapai secara jelas jika jenis vegetasi pohon peneduh diubah dari bentuk bulat dan gemuk menjadi bentuk ramping dan transparan. Segmen ini memiliki elemen vegetasi pohon yang dominan, 
namun sebaiknya vegetasi tidak seluruhnya menutupi bagian bangunan. Pemilihan jenis vegetasi dapat menciptakan kesan yang berbeda-beda dan dapat dibuat menyatu dengan perabot jalan.

Pada frame 5 kumpulan vegetasi pohon yang rindang menjadi pusat perhatian dari pandangan arah utara dan sekaligus menghalangi alur jalan selanjutnya. Posisinya sebagai closed view berpotensi untuk diolah menjadi sesuatu yang menarik, misalnya seperti membuka visibilitas focal point-3 dari vegetasi yang berkarakter gemuk dan bulat. Secara garis besar, ruang luar di antara focal point tidak mampu meningkatkan enclosure yang kuat.
Dapat disimpulkan pada serial vision segmen 1 ini adalah: pandangan dari arah Utara ke Selatan yang terlihat jelas hanya focal point-5 dan 2. Focal point5 merupakan menara yang menjulang dan dominan sebagai penyambut (isolation), dalam satu lingkungan juga merupakan hasil karya seni (building as sculpture). Focal point-5 hanya dapat ditangkap pada alur ini, sehingga penataan massa bangunan sebaiknya tidak menghalangi visi ini. Sedangkan focal point-4 sama sekali tidak tertangkap pada pandangan yang dilakukan secara serial vision. Focal point-4 terlihat lebih jelas pada pandangan dari arah Selatan ke Utara (Nugroho et al, 2013).

Tabel 2. Segmen 2 (Arah Utara ke Selatan)

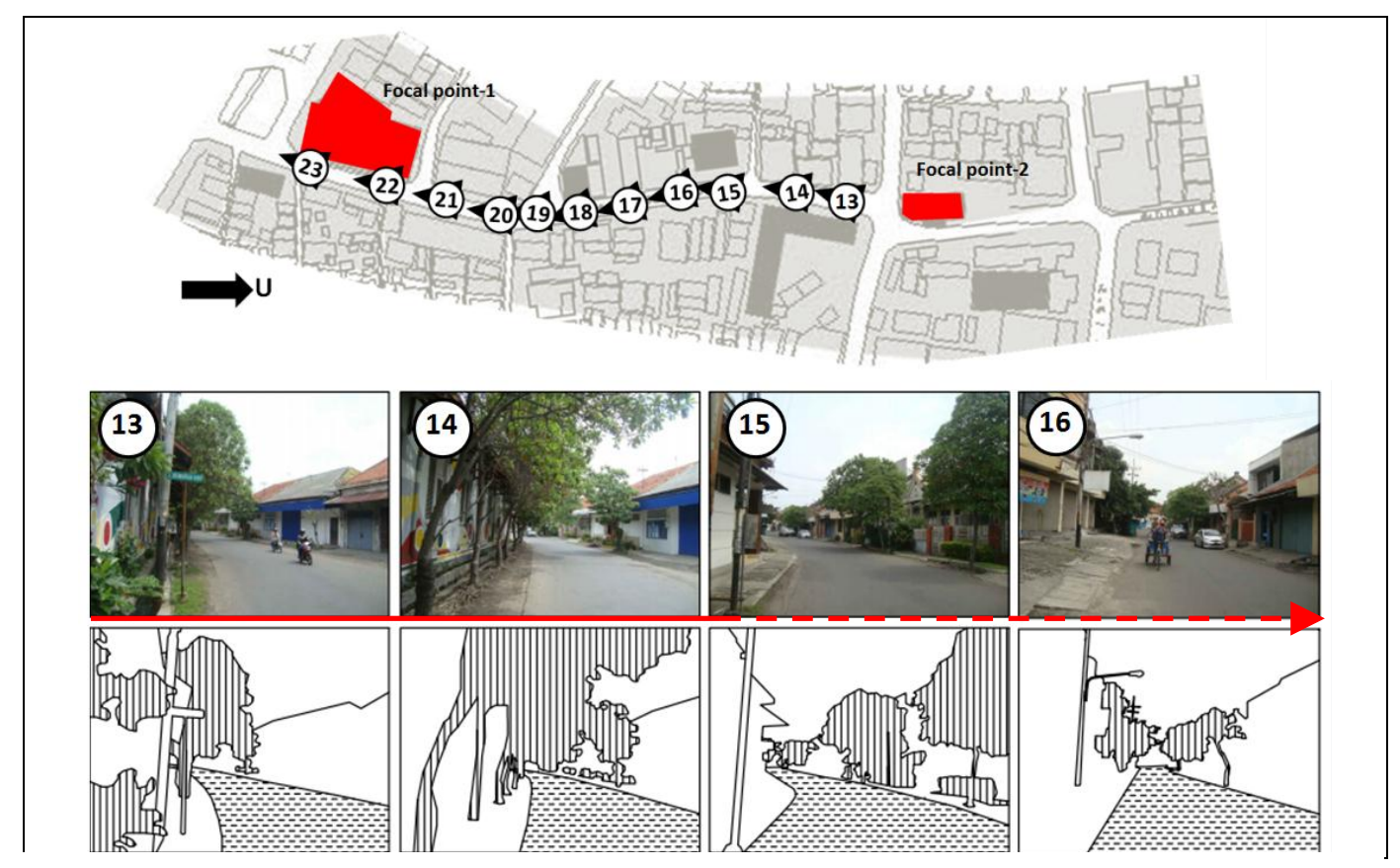



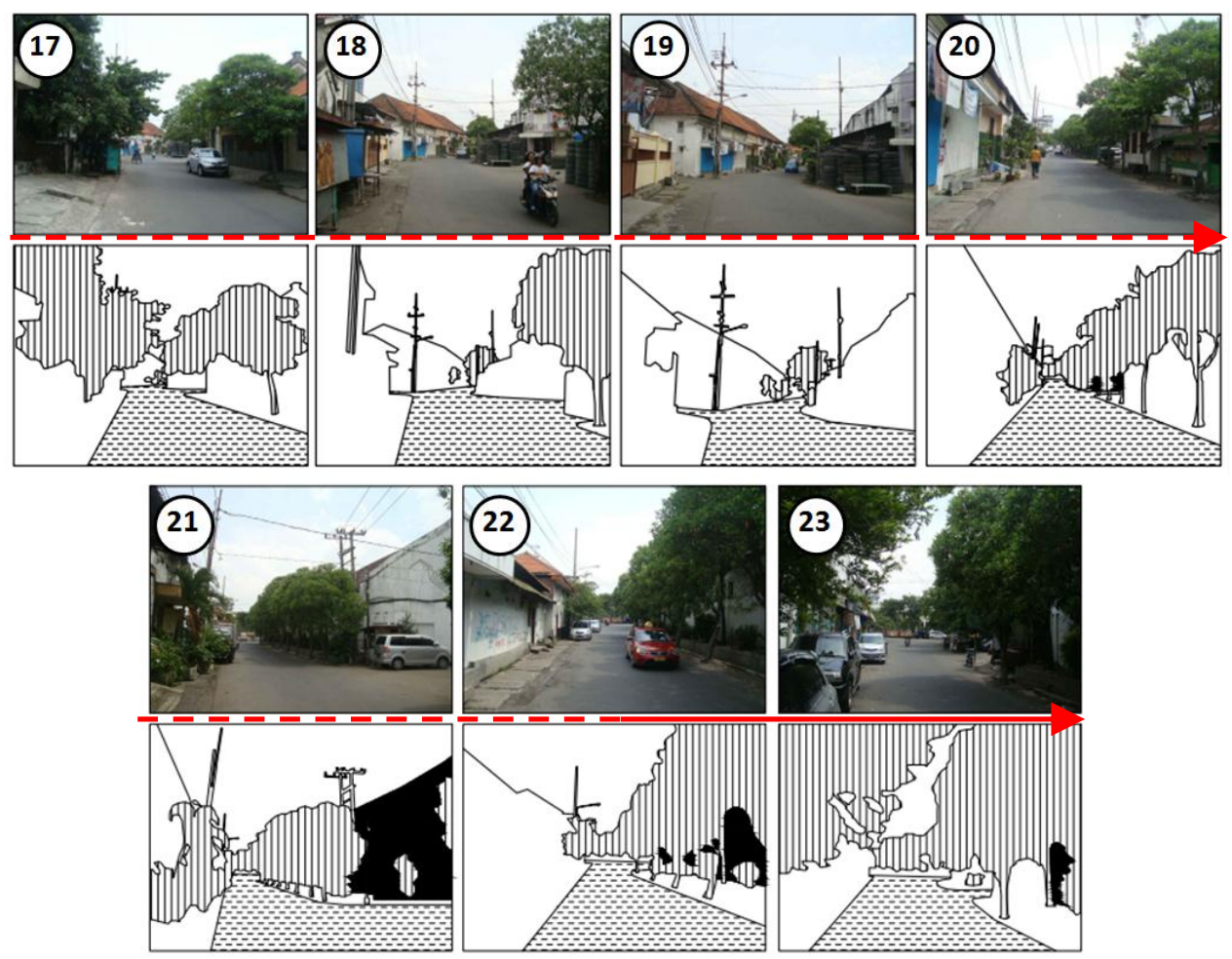

Sumber: Hasil Analisis, 2014

\section{Analisis Serial Vision Segmen 2}

Segmen 2 merupakan kelanjutan dari segmen 1 dengan jumlah 11 frames dan memperlihatkan 1 bangunan yang menjadi focal point. Analisis serial vision pada segmen 2 disajikan pada Tabel 2. Nomor frame dilanjutkan dari sebelumnya, sehingga dimulai dari nomor 13 hingga 23.

Bentuk jalan yang tidak lurus namun sedikit lengkung menciptakan perubahan pandangan yang bertahap (changing views). Permukaan fasad bangunan akan tertangkap seluruhnya dan lebih membangkitkan pengalaman merasakan ruang. Pada frame 13 hingga 19, tidak tertangkap sama sekali arsiran blok warna hitam (focal point). Pada sikuen ini tidak ada elemen yang menarik perhatian pengamat, sehingga diperlukan penataan lingkungan khususnya dari segi visual (perwujudan bangunan) dan spasial (permainan ruang) sebelum pengamat sampai pada pandangan focal point-1.
Pandangan menuju focal point-1 sedikit terlihat pada frame 20 dan lebih jelas pada frame 21. Focal point-1 berpotensi sebagai penanda masuk menuju kawasan, sehingga secara visual harus mudah tertangkap. Pandangan pada focal point-1 pada arah ini (Utara ke Selatan) lebih jelas jika dibandingkan dengan pandangan dari arah sebaliknya. Namun bangunan focal point-1 tampak terlihat sedikit lalu menghilang karena vegetasi pohon peneduh yang gemuk. Ini diperlukan penataan vegetasi yang tepat pada area sekitar focal point-1 sehingga visibilitas dan kenyamanan dapat tercapai keduanya. Skala ruang yang normal $(\mathrm{D} / \mathrm{H}=1)$ belum mampu menciptakan lingkungan yang baik. Ini disebabkan oleh tidak tersedianya jalur khusus pejalan kaki dalam lalu lintas yang ramai dengan kecenderungan kendaraan melaju kencang.

Dapat disimpulkan pandangan serial vision pada segmen 2 ini tidak terdapat 
elemen yang menarik hingga pandangan berakhir pada focal point-1. Bentuk jalan yang lengkung dan adanya keberadaan beberapa bangunan lama menjadi potensi untuk meningkatkan kualitas kawasan. Peningkatan ini harus mendukung visibilitas pada bangunan yang dijadikan focal point.

\section{Peningkatan Visibilitas}

Visibilitas pada focal point-1, 3, 4 dan 5 lebih mudah tertangkap dari pandangan arah utara ke selatan (dari pada arah sebaliknya). Ini berarti visibilitas bangunan hanya dapat dinikmati oleh pejalan kaki, mengingat bahwa arah lalu lintas kendaraan adalah dari selatan ke utara. Untuk meningkatkan visibilitas bangunan focal point, maka pemilihan jenis vegetasi sebaiknya tidak gemuk atau bulat khususnya pada focal point-1 dan 3. Rendahnya permainan tekstur dan material baik pada bidang dinding maupun lantai. Ini bertujuan untuk memberikan perbedaan ruang atau batas antara pejalan kaki dan pengguna kendaraan. Rendahnya permainan tekstur dan material juga menyebabkan menurunnya ketertarikan pada sebuah tempat.

Jalan yang melebar di persimpangan memiliki potensi yang besar menjadi ruang luar (square) khususnya di sekitar focal point 3, 4 dan 5. Selain itu visibilitas dapat ditingkatkan melalui penataan massa bangunan dan penyelesaian detail bangunan pada sudut persimpangan yang berpotensi menjadi titik tujuan pandangan.

Rangkuman tipe ruang townscape yang diperoleh dari pengamatan secara sikuensial arah utara ke selatan adalah sebagai berikut:
- Isolation, saat melalui sebuah koridor jalan kemudian pengamat melihat satu bangunan yang menjulang dominan. Isolation diterapkan pada focal point -5 pada frame 1 dan 2. Sesuai dengan namanya, menara yang tinggi seolah-olah berdiri sendiri dan terasing dari lingkungan lain (Gambar 5). Untuk dapat mencapai bangunan menara air, pengamat harus menempuh jalan lain (berputar).

- Building as sculpture, bangunan berfungsi sebagai monumen dalam kawasan dan bangunan sebagai hasil karya seni. Tipe ruang ini juga diterapkan pada focal point-5.

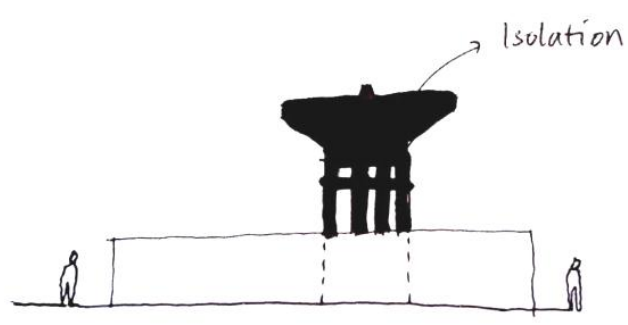

Gambar 5. Tipe ruang isolation pada lokasi studi.

Sumber: Dokumentasi Nugroho, 2015

- Projection, titik pusat perhatian disebabkan oleh penonjolan bagian bangunan terhadap sebuah lingkungan dan dijadikan titik orientasi kawasan. Penonjolan ruang dapat berupa menara pada sudut bangunan. Diterapkan pada focal point-2 karena bentuknya menjorok ke luar menjadi perhatian pengamat saat melalui jalan Krembangan barat.

- The colonnade, menciptakan banyak keuntungan bagi pejalan kaki seperti melindungi dari lalu lintas kendaraan yang padat, dari panas dan hujan. 
Cara meningkatkan visibilitas bangunan lama adalah dengan memperhatikan tipe ruang berdasarkan kajian townscape. Dari sekian banyak frame yang direkam melalui hasil analisis serial vision, diperoleh beberapa posisi dimana bangunan memiliki nilai yang potensial untuk dikembangkan dan dibangkitkan nilai arsitekturnya. Salah satunya adalah bangunan lama focal point-2 (Gambar 6). Gambar yang diambil dari frame 11 ini memiliki potensi visibilitas yang sangat baik (projection dan the colonnade). Namun, peran dari the colonnade sebagai jalan yang tembus kurang berperan besar dan penonjolan bangunan tidak memiliki nilai detail yang menarik.

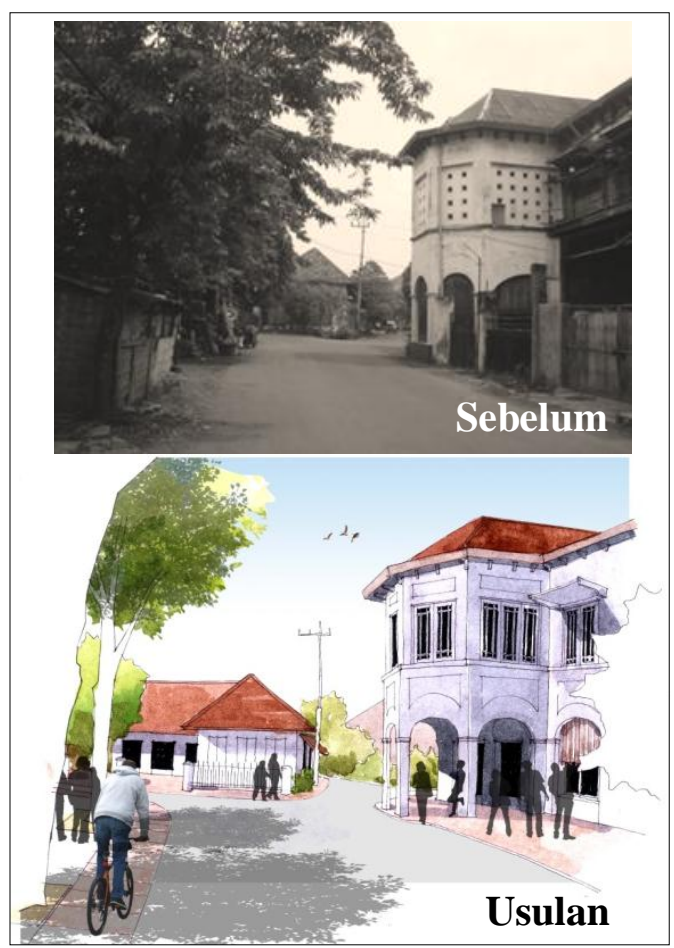

Gambar 6. Usulan desain skematik pada focal point-2 .

Sumber: Nugroho, 2014

Desain skematik yang diusulkan adalah membuka bidang masif pada dinding lantai dua dengan menggunakan jendela sehingga menciptakan permainan bayangan, timbul- tenggelam, solid-void. Selain itu penataan vegetasi dan jalur pejalan kaki juga mendukung visibilitas bangunan dan lingkungan. Penyediaan jalur pejalan kaki memberikan ruang bergerak (possession in movement). Pejalan kaki dapat menembus bagian bawah bangunan dan merasakan sebuah arcade, colonnade.

Banyak penelitian yang telah dilakukan di kawasan ini namun perhatiannya cenderung pada koridor jalan utama (Danardi et al, 2013) dan lebih kepada studi morfologi kawasan kota lama (Kwanda, 2011). Sejauh ini, belum pernah dilakukan penelitian yang lebih fokus pada beberapa bangunan yang berpotensi menjadi focal point kawasan di kawasan bagian dalam kota lama Surabaya. Sehingga, hasil yang diperoleh dari penulisan artikel ini dapat menambah wawasan dan masukan dalam meningkatkan kualitas lingkungan Krembangan Barat khususnya dalam melakukan pengalaman ruang secara sikuensial.

\section{Kesimpulan}

Dari sejumlah frame pengamatan sikuensial dari arah utara ke selatan, diperoleh bahwa bangunan lama yang berperan sebagai focal point, visibilitasnya rendah disebabkan oleh jenis vegetasi yang bulat dan lebat, dan terhalang oleh bangunan baru. Sebaiknya pemilihan jenis vegetasi adalah yang bersifat transparan dan ramping sehingga dapat menjaring view pada bangunan lama.

Seberapa besar tingkat visibilitas bangunan tidak hanya dilihat dari sudut pandang pengguna kendaraan, melainkan juga dari sisi pejalan kaki. Pejalan kaki masih kurang diperhatikan khususnya dalam hal penyediaan jalur 
pejalan kaki yang nyaman dan aman. Pejalan kaki memiliki kesempatan yang paling besar dalam melihat detail visual dan permukaan bangunan. Kajian yang dilakukan pada artikel ini adalah pandangan serial yang tidak dapat dinikmati oleh pengguna kendaraan bermotor. Dengan kata lain, visibilitas juga sangat dipengaruhi oleh arah pergerakan.

Upaya meningkatkan visibilitas yang lain adalah dengan melakukan perbaikan bangunan sehingga memiliki ketertarikan bagi pengguna jalan. Bangunan yang menjadi focal point adalah bangunan yang keberadaannya didukung oleh posisinya terhadap jalan. Sehingga saat bangunan yang dianggap focal point tadi memiliki kondisi yang baik, maka nilai arsitekturnya juga makin meningkat.

Teknik analisis serial vision sering digunakan dalam mengkaji sebuah pengalaman ruang, namun teknik segementasi data yang disajikan secara sikuensial belum pernah digunakan sebelumnya. Dengan menerapkan proses segmentasi data, pengamat akan lebih mudah melihat bangunan sebagai focal point dalam bentuk arsir hitam.

Teknik segmentasi data ini memiliki kelemahan jika diaplikasikan pada distrik yang memiliki keseragaman tipe bangunan (baik dari ketinggian maupun maju mundur bangunan). Teknik ini dapat dikembangkan dan dilengkapi dengan penyediaan data kuantitatif berupa proporsi jumlah arsiran dalam tiap frame untuk mengetahui seberapa besar intensitas vegetasi dan permukaan bangunan.

\section{Daftar Pustaka}

Al-Kodmany, K. (2001). Supporting imageability on the wolrd wide web (www): Lynch's five elements of the city in community planning. Journal of Planning and Environment B: Planning and Design, Volume 28, 805-832.

Almazán, J., Radovic, D., Suzuki, T. (2012). Small urban greenery: mapping and visual analysis in Kyōjima-Sanchōme. ArchnetIJAR, International Journal of Architectural Research, Volume 6, 57-76.

Cullen, G. (1961). Townscape. New York: The Architectural Press.

Danardi, W., Darjosanjoto, E.T.S. (2013). The visual connection in the main corridor within the Surabaya's old district. Proceedings of 7 th International Conference on Planning and Design (ICPD) in National Cheng Kung University, Tainan, Taiwan, 521-530.

Kalin, A., Yilmaz, D. (2012). A study on visibility analysis of urban landmarks: the case of Hagia Sophia (Ayasofia) in Trabzon. Journal of the Faculty of Architecture. Middle East Technical University, 241-271.

Kwanda, T. (2011). The morphological framework of the Chinese and the European districts in Surabaya, 1787-2005. Dimensi, Journal of Architecture and Built Environment, 38 (1), 1-13.

McCluskey, J. (1992). Roadform and townscape. 2nd edition. London: Architectural Press.

Nugroho, S., Darjosanjoto, E.T.S. (2013). Study on serial vision to improve visual quality of 
Krembangan district.

Proceedings of 7th

International Conference on

Planning and Design (ICPD) in

National Cheng Kung

University, Tainan, Taiwan, 491-500.

Nugroho, S., Darjosanjoto, ETS., Gunadi; S. (2014). Potensi bangunan lama sebagai focal point Kawasan Krembangan. Seminar Nasional Pascasarjana ITS XIV, Surabaya, Indonesia, Volume 3, 657-661.

Rollo, J., Barker, S. (2013). Perceptions of place evaluating experimental qualities of streetscapes. Proceedings of the $20136^{\text {th }}$ State of Australian Cities Conference, SOAC. Sidney, 111.

Trancik, R. (1986). Finding the lost space: Theories of urban design. New York: John Willey $\&$ Sons, Inc. 